\title{
Developing Appreciative Literature Textbook Based on Thematic- Integrative Through Active Learning
}

\author{
Endang Sri Markamah ${ }^{1}$, St. Y. Slamet ${ }^{2}$, Rukayah $^{3}$, Retno Winarni ${ }^{4}$
}

\begin{tabular}{l} 
ARTICLE INFO \\
\hline Article History: \\
Received 18.12.2018 \\
Received in revised form \\
21.03 .2019 \\
Accepted \\
Available online 01.07 .2019
\end{tabular}

\begin{abstract}
The objectives of this research were: (1) to describe students' and lecturers' needs on poetry and drama appreciative textbook, (2) to describe the development of textbook model (3) to find the effectiveness of textbook model 4) to describe textbook dissemination. The ty pe of research used was research and development. Research was done through 4 stages: (1) exploration, (2) model development, (3) model testing, (4) dissemination. Exploration stage used qualitative descriptive approach. Data was collected through in-depth interviews, observation, documentation, and questionnaires. Data analysis technique was interactive analysis model. Model testing was done through experimental research. The results of this research were: (1) the exploration stage showed that the poetry and drama learning textbook used by Elementary Teacher Education Program (ETEP) students in Surakarta did not meet the students' and lecturers' need, (2) model development stage produced appreciative poetry and drama textbook through preliminary field testing; (3) model testing phase was to testeffectiveness of the textbook used t-test non-independent technique. It was obtained to btain of 23 and ttable $(90 ; 0.05)$ of 1.67 . Thus, to btained (23) > ttable (1.67) which meant that the hypothesis was accepted (Ho was rejected). In conclusion, the Appreciative Poetry and Drama textbook model was effectively improve students' poetry and drama appreciation skills. Dissemination was done through national seminars, article writing in international journals, as well as the publishing of an Integ rative-thematic Textbook of Poetry and Drama Learning with ISBN.
\end{abstract}

Keywords:

(C) IJERE. All rights reserved

Textbook, poetry and drama, appreciative, thematic-integ rative, active learning.

\section{INTRODUCTION}

Based on the observation done by the researchers, conditions that occur in the study of literature in Undergraduate ETEP in Surakarta was still not encouraging. Therefore, it was important to make efforts to develop appreciative literary learning textbooks based on thematic-integrative through active learning. The expected textbooks were more appropriate, according to the needs and characteristics of students, to help the students to improve the poetry and drama appreciation skill.

Another problem that $\mathrm{w}$ as encountered $\mathrm{w}$ as that the process of literary learning $\mathrm{w}$ as still conventional. Learning was lecturer-centered. Lecturers' lack of adequate teaching materials and presentation methods were not in accordance with the students' interests and conditions. This lead to boring learning and low level of literary appreciation. One of the reasons w as the teaching materials that was not in accordance with the existing context.

Based on the results of in-depth interview with students and lecturers, the Undergraduate ETEP students' ability to appreciate literature (poetry and drama) in Surakarta region as a candidate for elementary school teachers had not achieved the standard. The lack of capability was due to lessappreciative and integrative learning strategies. Literary appreciation learners had not been taught to enjoy, appreciate, value, and utilize literary works to develop personality, expand life insight, and improve language skills.

The phenomenon of less successful literary learning in undergraduate ETEP could be due to the low level of students' ability to appreciate poetry and drama. This was due to the limitations of textbooks as a reference. The existing or commonly used lecture books had not fully supported the success of students' poetry and drama appreciation abilities. The lecturers had not implemented the learning by using innovative learning model.

\footnotetext{
1 endangsri54@staff.uns.ac.id, Sebelas Maret University, Indonesia. https://orcid.org/0000-0001-9327-1827

2 st_ys@staff.uns.ac.id Sebelas Maret University, Indonesia. https://orcid.org/0000-0002-9851-4733

3 rukayah@staf.uns.ac.id Sebelas Maret University, Indonesia. https://orcid.org/0000-0002-5987-1850

4 retnowinarni@staff.uns.ac.id, Sebelas Maret University, Indonesia. https://orcid.org/0000-0003-1110-6890
} 
Active learning is activities that help students to test their feelings, values, and behaviors (Silberman, 2006). Silberman describes that in active learning, students do a lot of activities. Students use their brains to learn ideas, solve problems, and apply what they learn. According to Lorenzen (2001) active learning is a method of inviting students to participate actively in the classroom. Active learning aims to optimi ze the use of all potentials possessed by students, so that all students can achieve satisfactory learning outcomes according to their personal characteristics.

Cherney's research (2008) concluded that the application of active learning is based on the lev el of the program, the material, the type of student, the type of class, and the discussion required by the students to improve the understanding of the material. Meyers \& Jones (1993) concluded that by applying active learning strategies, students can express four language skills: listening, speaking, reading, and w riting. Both researchers proved that active learning can improve the ability to appreciate poetry and drama.

Prince (2004) research concluded that the choosing of active learning strategy was a correct choice to make the learning process effective. Active learning is an effective learning strategy compared to the other conventional strategy. The advantages of active learning are: (1) students will learn more material; (2) the student may keep the information longer; and (3) students like learning, teachers, and classroom conditions more as it is something new and variative. Active learning allow s students to study in the classroom with or without the help of teachers or other students.

Mustakim's research (2010) concluded that the learning of literature appreciation in the new school was limited to literary understanding, and had not touched the inferential, evaluative, and appreciative abilities. This could not be separated from the general fact that literary learning in schools was still around the literary discussion, memorizing the work, and the implementation of learning by using the lecture method. The problem that often occured in literary learning $w$ as that the learning had not been able to $m$ ake students to have an understanding of the literary appeal and the main purpose of literary learning.

Good literary learning should be able to help students' language skills, enhance cultural knowledge, develop inventiveness and taste, and support the formation of character (Moody, 1971). The purpose of the study of literature is to be able to enjoy, understand, and utilize literary works to develop personality, broaden life insight, and improve knowledge and language skills (Nurhidayati, 2011). The main purpose of teaching literature is to provide opportunities for learners to gain literary experience with the ultimate goal of appreciating literature (Gani, 1998). Judging from the value of education, literature has the benefits of (1) accelerating language development through listening and reading of literature, (2) developing w riting skills, as there is a correlation between reading skills and w riting skills; and (3) developing cross-curriculum skills by learning various know ledge through literature (Supriyadi, 2007).

In language and literature learning, integrative concept refers to the understanding of the presentation of learning materials of language and literature in an integrated manner. Language material (structure and vocabulary) with language skills (listening, speaking, reading, and writing) in the implementation of learning activities, the presentation of the material presented in an integrated. Literary listening activities can be integrated with speaking activities, for example, retelling, question-answer, discussion or soliciting feedback. In addition, listening activities can be integrated with reading, w riting, and even four language skills at once.

The success of appreciative and integrative literary learning should be supported by the availability of an integrative thematic-based poetry and drama learning textbook. Textbooks contains specific materials used as a teaching and learning guide at school (Richards \& Rodgers, 2002). Textbooks are usually used in conjunction with other learning resources such as workbooks, teacher reference books or supporting texts (Tomlinson \& Masuhara, 2008). In order to fulfill the textbook, this research is urgently needed to be done.

\section{METHOD}

The type of research used in this study was a development study developed by Borg and Gall (2003). Furthermore, Borg and Gall said that research and development w as a process used to develop and validate educational products. The research included four stages: (1) exploratory stage, (2) model development stage, 
(3) model testing stage, and (4) dissemination and model implementation stage (Sukmadinata, 2010; Nurkamto, 2012).

Exploration stage was done in-depth study on the implementation of appreciative poetry and drama lesson based on thematic-integrative in undergraduate ETEP Surakarta. The purpose of this activity was to analyze the students' and lecturers' needs on textbooks that are considered capable to improve the students' ability in appreciating poetry and drama optimally. The research approach used was qualitative descriptive approach. Researchers emphasize the observation on the interaction between students and lecturers in the implementation of appreciative poetry and drama learning at the research location. Researchers also conducted interviews and questionnaires to students and lecturers, and also analyzing documents related to research problems.

The data of this study were obtained from various data sources available at the study sites. Type of data sources used were: 5 students with the age of 19 and 20 years old and 5 lecturers, poetry and drama appreciation classroom activity, and documents or archives. Data collection techniques used were in-depth interviews, observation, documentation, and questionnaires. Data analysis was done using interactive analysis model (Miles and Huberman, 1992; Sutopo, 2002), conducted in 2 stages: during data collection and after data collection.

In the model development stage, the main objective $w$ as to produce appreciative poetry and drama textbook model based on thematic-integrative. The development of a prototype textbook model was done in a cycle, which was both research and practice (Gall et al, 2003). The steps taken include: preparation of prototype, implementation, evaluation of implementation, and revision in a sustainable manner. The procedure used was the Glanz model theory guide (in Gall et al, 2003), which includes: data collection, analysis, data interpretation, reflection, and modification. Continued using the same procedure in the next cycle. In addition, the Zuber-Skeritt model was also used (in Cohen, 2000), which includes: careful planning, implementation of plans, observation, assessment, evaluation, critical analysis of implementation results, and subsequent cycle determination.

The form of development was done by way of testing the textbook prototype in the field through limited trials and extensive trials. A limited trial was conducted on the undergraduate ETE Program of Sebelas Maret University Surakarta. Extensive trials were conducted on the Undergraduate ETE Program of Muhammadiyah University Surakarta and undergraduate ETE Program of UNISRI Surakarta.

Data collection techniques used were in-depth interviews, participant observation, document analysis, tests, and focus group discussions. Data analysis was done in two ways; qualitatively and quantitatively. The model that has been tested was then consulted with the expert in order that the developed textbook model has substantive truth and quality. The experts who did the validati on was Prof. Dr. Herman J. Waluyo, M. Pd. (literary learning expert) lecturer of Sebelas Maret University Surakarta.

The testing phase of the model aimed to test the effectiveness of appreciativeliterary textbook model that is based on thematic-integrative in improving the students' ability to appreciate poetry and drama. Model testing was done by conducting experimental research. The type of experimental research used was quasi experimental research. The experimental research design chosen was Quasy-Experimental Design Model Non-Equivalent Before-After Design (Wiersma, 1986; Cohen et al. 2000; Sugiyono 2013). The experimental procedures used are the concepts of Gall, Gall, \& Borg (2003) and Cohen (2000).

The experimental group used was 90 students of Undergraduate ETE Program of Sebelas Maret University Surakarta who were about 20-22 years old and consisted of 33 males and 57 females comef from various ethnique who was at the moment having a poetry lesson in their 5 th semester. The control group was 90 students of Undergraduate ETE Program of Muhammadiyah University Surakarta who were about 20-22 years old and consisted of 62 females and 28 males comef from various ethnique who was at the moment having a poetry lesson in their 5 th semester. The design of this study was to look at the main effect of the appreciative literary textbook based on thematic-integrative on the students' ability to appreciate poetry and drama. The data collection technique used was a test on the ability to appreciate poetry and drama. The analysis of the research data was done through two stages, the requirements analysis (normality test, homogeneity test, and balance test) and the data analysis to test the effectiveness of the model (non- 
independent test). The output of the model testing stage was a thematic-integrative based appreciative poetry and drama textbook that has been tested in a process and product.

The dissemination stage was disseminating the developed textbook in a hope that the textbook could be implemented in an appreciative poetry and drama lessons especially in universities which had undergraduate ETE Program in Surakarta. Dissemination was done through national seminars, article writing in international journals, as well as published as an ISBN textbook.

\section{RESULT}

Based on the findings at the exploratory stage, it could be concluded that there were problems in the literature study of the Elementary Teacher Education Program (ETE Program). Those problems were: (1) the absence of appreciative poetry and drama textbooks that is based on thematic-integrative, (2) the lack of activity to improve the students' poetry and drama appreciation, (3) the lack of lecturers' understanding on poetry and drama appreciation material, and (4) the uninnovative learning model and unintegrative approach in literary learning process. In principle, students, lecturers, and policy makers agreed that an thematic-integrative based poetry and drama appreciation textbook needed to be developed.

There are six attempts at the development stage; they ar e: (1) developing prototy pe into textbook; (2) development of prototype model based on expert's judgment, (3) result of development and improvement of model based on limited trial, (4) model development result based on broader trials, (5) the establishment of textbook models, and (6) the conclusion of the development of the model.

\section{Data Description of the Students' Ability in Appreciating Poetry and Drama}

Textbook model testing was done by giving pre-test to 90 undergraduate students of ETE Programs in Surakarta before experiment (pre-test) and after the experiment (post-test). Pre-test was held to know concretely, the students' ability to appreciate poetry and drama before the experiment was conducted. Instead, post-test were conducted to know concretely the final state of the students' ability to appreciate poetry and drama after the experiment was conducted.

Referring to the explanation, there are two description of the research data in the testing phase, they are: (a) pre-test score and (b) post-test score.

\section{a. Students' pre-test score data analysis}

Based on the descriptive analysis, some points could be revealed: (1) central tendency: mean $=52.07$, mode $=60$, and median $=53.5 ;$ (2) spread tendency: variance $=81.37$ and standard deviation $=9.02 ;$ (3) the highest score $=74$; and the lowest score $=30 ;(4)$ span $=44$.

The frequency distribution of the pre-test score of the students' ability to appreciate poetry and drama was obtained through the calculation stages as follows:

1) Determine the range, ie by reducing the largest data with the smallest data: $74-30=44$;

2) Determine the number of interval classes. This study used 6 classes;

3) Determine the length of the interval class by way of the range value divided by number of interval classes, $44: 6=7.33$, which then rounded to 8 .

4) Choose the lower end of the first interval class. This is done by taking the smallest data. Therefore, the first interval class starts from a score of 30 .

Based on the above steps of preparing the frequency distribution of the scores, the frequency distribution of the students' pretest score on the ability to appreciate poetry and drama could be seen in Table 1 below.

Table 1. frequency distribution of the students' pre-test score

\section{Interval Class}

\section{Absolute Frequency}

(f abs)
Relative Frequency

(\%)

$$
\text { (f rel.) }
$$




\begin{tabular}{ccc}
\hline $30-37$ & 6 & 6,67 \\
\hline $38-45$ & 15 & 16,67 \\
\hline $46-53$ & 24 & 26,67 \\
\hline $54-61$ & 36 & 40,00 \\
\hline $62-69$ & 8 & 8,89 \\
\hline $70-77$ & 1 & 1,11 \\
\hline & 90 & 100,00
\end{tabular}

\section{b. Students' post-test score data analysis}

Based on the descriptive analysis, some points could be revealed: (1) central tendency: mean $=74.96$, mode $=78$, and median $=75.5 ;$ (2) spread tendency: variance $=35.46$ and standard deviation $=5.95 ;(3)$ the highest score $=88$; and the lowest score $=60 ;(4) \mathrm{span}=28$. As the steps of preparing the frequency distribution, the preparation of the frequency distribution of the post-test score obtained: 1 ) range $=28$; (2) the number of the interval class $=6$; (3) the length of the interval class $=4.67$ rounded to 5 ; and (4) the lower end of the first interval class starts from the smallest data of 60 .

Based on the above steps of preparing the frequency distribution of the scores, the frequency distribution of the students' post-test score on the ability to appreciate poetry and drama could be seen in Table 2 below.

Tabel 2. frequency distribution of the students' post-test score

\begin{tabular}{|c|c|c|}
\hline Interval Class & $\begin{array}{l}\text { Absolute Frequency } \\
\qquad\left(f_{\text {abs }}\right)\end{array}$ & $\begin{array}{l}\text { Relative Frequency } \\
\qquad \begin{array}{c}(\%) \\
\text { (f rel.) }\end{array}\end{array}$ \\
\hline $60-64$ & 3 & 3,33 \\
\hline $65-69$ & 14 & 15,56 \\
\hline $70-74$ & 26 & 28,89 \\
\hline $75-79$ & 23 & 25,56 \\
\hline $80-84$ & 20 & 22,22 \\
\hline $85-89$ & 4 & 4,44 \\
\hline & 90 & 100,00 \\
\hline
\end{tabular}

\section{Requirement Analisis}

Inferential data analysis to prove whether this research hypothesis accepted or rejected was done through statistical test with non-independent $t$-test. Data analysis with statistical techniques required some requirements analysis. These requirements include: (a) data normality test, and (b) homogeneity of variance test. The data normality test was performed using Lilliefors technique. Meanwhile, the homogeneity of variance test was performed using the Bartlett's technique.

\section{a. Normality test}

There were two class of data tested for normality in this research: pre-test data and post-test data. Here were the normality test results for both groups of data above.

\section{Normality test result of the Pre-test data}


From the result, it showed that the maximum Lo was 0.0778 . From the list of critical values $\mathrm{L}$ for Lilliefors test with $\mathrm{N}=90$ and the real level $\alpha=0.05$ obtained $\mathrm{Lt}=0.0934$. From the above comparison it appears that Lo was smaller than Lt, so it could be concluded that pre-test data came from the normal distributed population.

\section{Normality test result of the Post-test data}

From the result, it showed that the maximum Lo was 0.0699 . From the list of critical values L for Lilliefors test with $\mathrm{n}=90$ and the real level $\alpha=0.05$ obtained $\mathrm{Lt}=0.0934$. From the above comparison it appears that Lo was smaller than Lt, so it could be concluded that pre-test data came from the normal distributed population.

\section{b. Homogeneity of Variance}

This homogeneity of variance test $w$ as conducted to test the similarity of variance between the pretest score and post-test score of the students' ability to appreciate poetry and drama. The statistical technique used for this purpose was Bartlett's technique. This test was intended to test the null hypothesis $\left(\mathrm{H}_{0}\right)$ which stated that the variance between the pre-test score and post-test score w as homogeneous at the real level $\alpha=$ 0.05. Its alternative hypothesis $\left(\mathrm{H}_{1}\right)$ suggested that the variance between pre-test score and post-test score was not homogeneous at the same level of reality.

The test criterion used is that $\mathrm{H}_{0}$ is rejected if it turns out that $\chi_{\text {onserved }}^{2}$ is smaller or equal to $\chi_{\text {table }}^{2}$ at the real level of $\alpha=0.05$. Conversely, if $\chi_{\text {onserved }}^{2}>\chi_{\text {table }}^{2}$ at a real level $\alpha=0.05$, then $\mathrm{H}_{0}$ is accepted.

Homogeneity of variance test resulted on $\chi_{\text {onserved }}^{2}=15.16$. From the chi-squared distribution table with $\mathrm{df}$ (degrees of freedom) 1 and the significant level $\alpha=0.05$ it was obtained $\chi_{\text {table }}^{2}=38.4$ which is much greater than $\chi_{\text {onserved }}^{2}$. Thus, based on the testing criterion, the null hypothesis $\left(\mathrm{H}_{0}\right)$ which states that the pretest score and post-test score is not homogeneous was rejected. The conclusion is that the variance of pre-test and post-test score was homogeneous.

Based on these two test results, it could be concluded that the analysis requirements required for data analysis with non-independent $t$-test statistics techniques have been met, so it is feasible for further analysis to see the difference in the effect of using the appreciative poetry and drama textbook model based on thematic-integrative, in improving the students' ability to appreciate poetry and drama.

\section{Hypothesis Testing}

Hypothesis testing here was intended to determine whether the proposed null hypothesis $\left(\mathrm{H}_{0}\right)$ was rejected, or vice versa at a certain level of confidence the proposed alternative hypothesis (H1) was accepted. In accordance with those mentioned in the previous section, the hypotheses testing was tested using nonindependent $t$-test techniques. The statistical analysis technique was used to observe the effectiveness of the treatment in the use of a thematic-integrative based poetry and drama appreciation textbook model, with those who did not use the textbook model in improving the undergraduate ETEP students' ability to appreciate poetry and drama in Surakarta region.

Based on statistical analy sis with non-independent t-test technique, tobtained was 23 , while table with $\mathrm{N}$ $=90$ at level $\alpha=0,05 \mathrm{w}$ as 1.67 . Referring to the hypothesis testing criteria, it could be concluded that the use of thematic-integrative based poetry and drama appreciation textbook was very effective and significant in improving the undergraduate ETEP students' ability to appreciate poetry and drama in Surakarta region, rather than being taught not using the textbook model.

\section{DISCUSSION}

Facing the low condition of the ETEP students's ability in appreciating poetry and drama based on the researchers' observation and interview done as a preliminary research, it is conclude that the development of thematic-integrative based poetry and drama appreciation textbook through active learning was an urgent need. Active learning and thematic-integrative learning was choosen as it is inline with several researches done by Gul (2014); Toivanen, Komulainen, and Ruismaki (2011); and Nordin at.el. (2012) which mentioned that active learning and thematic-integrative learning stimulate an active improvement of language features; listening, speaking, reading, and learning. 
Gul (2014) found out that active learning with drama practice $w$ as able to improve the students' logical thingking in order to combine knowledge that they have had, attitude, social values, their understanding of a certain cases, and their own individual responsibility to develop their critical thinking, logical thingking, and taking decission. Toivanen, Komulainen, and Ruismaki (2011) also found out that drama lesson is a good and effective learning process. It is due to dramma lesson is able to accomodate the students to perform confidently, creative, and improve students' ability in developing ideas. Through drama lesson, the students are actively involved in combining their language competence sich as listening, speaking, reading, and w ritting (Nordin at el., 2012)

The result of this research itself indeed inline with those previous research. Textbook which was developed by the researcher which involved active learning was proofed significant in improving the students' appreciative ability both for literature and drama. The thematic integrative learning used in this texbook brings meaningfulness in the learning process. As it was stated in the result section, the use of thematicintegrative based poetry and drama appreciation textbook was very effective and significant in improving the undergraduate ETEP students' ability to appreciate poetry and drama in Surakarta region, rather than being taught not using the textbook model. This research showed that active learning and thematic integrative learning which was used as the basis of the textbook development could help the students to improve their appreciative ability compared to those who did not use the developed textbook.

\section{CONCLUSION}

The exploratory stage showed that the textbook of poetry and drama lesson used in the undergraduate ETE Program in Surakarta region had not been in accordance with the students' and lecturers' needs. The model development stage produced an appreciative textbook through preliminary field testing. The effectiveness testing phase with non-independent $t$-test technique obtained $t$-obtained of 23 then consulted with t-table

(with $\mathrm{N}=90, \alpha=0.05)=1.67$. Thus, $\mathrm{t}$-obtained (23) $>\mathrm{t}$-table (1.67), then the hypothesis $\mathrm{w}$ as accepted (Ho was rejected). Thus, a Thematic-Integrative based Poetry and Drama Appreciation Textbook was effectively tested to improve the students' ability to appreciate poetry and drama. This finding is in line with the other research findings that active learning in teching literature will brings several advantages for the students, such as stimulate an active improvement of language features, accomodate the students to perform confidently, develop crativity, and improve their appreciative ability.

Though the research on the development of appreciative literature textbook based on thematicintegratıve through active learning has shown a sucess, this research still indeed has limitation. This research is limitted for the sample used since it was done with 90 samples from 2 different university in Surakarta. It is due to the limmitation of time and fund. This limitation of the sample brings limitation on the generalisation of the result of the research. Due to the limittation of this research, it could be a suggestion for the next researcher to widen the sample used so that the research result could be generalized to the whole population.

\section{REFERENCES}

Borg, W. R. dan Gall, M. D. (2003). Educational research: An Introduction. New York: Longman.

Cherney, I. D. (2008). The effects of active learning on student' memories for course content. Journal of Active Learning in Higher Education, Volume 9, No. 2. pp. 152-171. http//alh.sagepub.com/cgi/content/abstract/9/2/152.

Cohen, L. et al. (2000). Research method in education. Great Briatin: TJ International Ltd, Padstow, Cornw all.

Gani, E. (2003). Efektifitas Pengajaran Menulis. Dalam http://www.ialf.edu.html. Diunduh pada tanggal 24 Mei 2018.

Gul, E. \& Gucum, E.B. (2014). Creative drama appreciation as complementary for constructivist approaches for science sources: Teacher and student's evaluation. Procedia Social and Behavioral Science No.174 pg 2043-2050. Elsevier ScienceDirect.

Lorenzen, M. (2001). Active learning and library instruction (online) dalam http://www.libraryinstruction.com/link.html. 
Meyers, Chet \& Jones, Thomas B. (1993). Promoting active learning. Jossey-Bass Publisher: San Fransisco.

Miles, M. B. dan Huberman, A. Michael. (1992). Analisis data kualitatif. (terj. Tjetjeo Rohendi Rohidi)). Jakarta: universitas Indonesia.

Moody, H.L.B. (1971). The teaching of literature. London: Longman.

Mustakim, A. W . (2010). Psikologi Pendidikan. Jakarta: Rineka Cipta

Nordin A.N., et.al. (2012). Fulfilling the task of reading, writing, speaking and listening through drama workshop. Procedia Social and Behavioral Science No. 66 pg. 196-202. Elsevier ScienceDirect.

Nurhidayati (2011). Pembelajaran menyimak apresiasif cerita pendek dengan strategi belajar kooperatif. Litera. 10. (1): 87-99.

Nurkamto, Joko. (2012). Struktur Penelitian danPenulisan R \& D Bidang Pendidikan (Versi Borg dan Gall). Makalah Kuliah Umum Program Pascasarjana IKIP PGRI Madiun : 30 September 2012.

Prince, M. (2004). Does active learning work: a review of the recearch. Journal Engr. Education, 93 (3): $223-$ 2231. Deparment of Chemical Engineering Bucknell University.

Richard, JC \& Rodgers T. (2002). Approaches and Methods in Language Teaching. Cambridge: Cambridge University Press.

Silberman, M. (2006). Active Learning; 101 Strategi Pembelajaran Aktif. Terj. Sarjuli, et al. Yogyakarta: YAPPENDIS.

Sugiyono (2013). Metode Penelitian Kuantitatif dan R \& D. Bandung: Alfabeta.

Sukmadinata, N. S. (2010). Metode Penelitian Pendidikan. Bandung: Remaja Rosdakarya.

Supriadi, D. (2007). Kreativitas, Kebudayaan, dan Perkembangan Iptek. Bandung: CV Alfabeta

Sutopo, H. B. (2002). Metodologi Penelitian Kualitatif. Surakarta: Sebelas Maret Univercity Press.

Toivanen, T., Komulainen, K., Ruismaki, \& Heikki. (2011). Drama education and improvisation as a resource of teacher students's creativity. Procedia Social and Behavioral Science No. 12 pg. 60-69. Elsevier ScienceDirect.

Tomlinson,B. \& Masuhara (Eds). (2004). Developing language course materials. Singapore: RELC Portfolio Series.

Wiersma, W. (1986). Research methods in education: An introduction. Boston: Allyn and Bacon, Inc. 